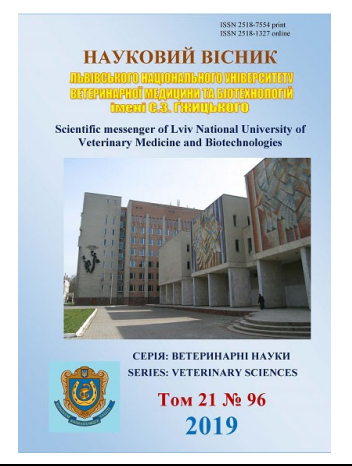

\author{
Науковий вісник Яьвівського національного університету \\ ветеринарної медицини та біотехнологій імені С.3. Гжицького. \\ Серія: Ветеринарні науки \\ Scientific Messenger of Lviv National University \\ of Veterinary Medicine and Biotechnologies. \\ Series: Veterinary sciences
}

UDC 616.022.085.33

\title{
Effect of fluoroquinolones on the male chicken reproductive organs
}

\author{
H.A. Fotina, Y.M. Opanasenko \\ Sumy National Agrarian University, Sumy, Ukraine
}

Article info

Received 08.10.2019 Received in revised form 11.11.2019

Accepted 12.11.2019

Sumy National Agrarian University, G. Kondrat'eva Str., 160, Sumy, 40000, Ukraine.

Tel.: +38-099-238-62-24

E-mail.: super.annafotina@ukr.net
Fotina, H.A., \& Opanasenko, Y.M. (2019). Effect of fluoroquinolones on the male chicken reproductive organs. Scientific Messenger of Lviv National University of Veterinary Medicine and Biotechnologies. Series: Veterinary sciences, 21(96), 86-89. doi: 10.32718/nvlvet9615

The using of antibiotics in poultry has some disadvantages. The problem of antibiotic resistance of microorganisms is recognized globally and is currently one of the strategic goals worldwide. Fluoroquinolones are an important and large group of synthetic antimicrobials that have great importance in the treatment of infectious-inflammatory poultry diseases of different etiologies. Fluoroquinolones have high bactericidal activity against a number of bacterial pathogens that infect poultry including E. coli, Hebsiell spp., Pseudomonas spp., Staphylococoeus spp. and Chlamydia spp. Enrofloxacin (ENR) is an antimicrobial agent belonging to the group of third-generation fluoroquinolones. ENR has been historically used as veterinary medicine for treatment of gastrointestinal and respiratory infections in several animal species, including poultrys cursing diseases caused by gram-positive and negative bacteria. Enrofloxacin presents 1,4dihydro-1-cyclopropyl-7-(4-ethyl-1-piperazinyl)-6-fluoro-4-oxo-3-quinoli;3-quinoline carboxylic acid. A further synthesis allowed the reaching of active substances of cyclopropyl, as an antibacterial action to get further extension. A crystalline active substance with faint yellow color that was obtained to develop in high purity, is hardly soluble in water at pH 7, but as the molecule contains acidic and basic groups, it is easily dissolved at both alkaline and acid pH. The goal of the work. The purpose of our study was to investigate the sperm of male chicken after the use of enrofloxacin and to identify metabolites. Materials and methods of research. The researches were conducted in the conditions of vivarium clinics of the veterinary faculty and laboratories of the department of epizootology and parasitology of Sumy National Agrarian University. 80 male chickens were placed for research, which were kept in metal cages for 5-6 individuals. The use, care and transportation of birds for toxicological research were with all applicable animal welfare laws. All reasonable steps were taken to avoid or minimize discomfort, distress or pain of birds. Results of research and discussion. The differences between normal motility and defect sperm in control and enrofloxacin treated birds were not founded. Weight of testes, wattles and combs was not affected by drug. Ascorbic acid, total protein, testosterone and cholesterol concentration were similar in control and enrofloxacin treated groups. It is suggested that enrofloxacin at doses used were safe for male chicken. The administration of the drug "Enzin 10\%" to the male chicken did not affect the concentration of ascorbic acid in the testicles, total protein and cholesterol. These indicators are actively involved in spermatogenesis. Thus, it can be concluded that the use of the drug "Enzin 10\%" at therapeutic doses for 10 days had no negative effect on spermatogenesis of the male chicken.

Key words: enrofloxacin, antibiotic resistance, male chicken, animal welfare laws.

\section{Вплив фторхінолонів на репродуктивні органи півників}

\author{
Г.А. Фотіна, Ю.М. Опанасенко
}

Сумський національний аграрний університет, м. Суми, Украӥна

Застосування антибіотиків в птахівництві викликає все більше занепокоєння, адже це несе певні небезпеки. Проблема антибіотикорезистентності мікроорганізмів визнана глобальною і в даний час є одним із стратегічних завдань у всьому світі стримування розвитку і розповсюдження антибіотикорезистентних мікроорганізмів. Фторхінолони мають високу бактерицидну активність щүодо низки бактеріальних збудників, які викликають інфекційні хвороби птахів, включаючи E. соli, Неbsiell spp., Pseudomonas spp., Staphylococoeus spp. i Chlamydia spp. Фторхінолони - високоефективні синтетичні антибіотики иирокого 
спектру антимікробної дії, які застосовуються для лікування бактеріальних інфекцій уже 40 років. Це препарати зі специифіним механізмом дії на бактеріальні клітини. Вони блокують фермент ДНК-гіразу бактеріальної клітини внаслідок чого знижується активність ферменту та процес суперспіралізаціції хромосом стає не можливим. Це призводить до порушення поділу бактеріальної клітини. Метою нашого дослідження було дослідити сперму півників після вживання енрофлоксацину та виявити його метаболіти. Дослідження проводилися в умовах клінікі віварію ветеринарного факультету та лабораторії кафедри епізоотології та паразитологї Сумського національного аграрного університету. Для дослідження було розмімено 80 півників, яких утримували в металевих клітках по 5-6 особин. Використання, догляд та транспортування птахів для токсикологічних досліджень відповідали всім чинним законам про охорону тварин. Були вжиті всі розумні кроки, щяоб уникнути чи мінімізувати дискомфорт, страждання чи біль птахів. Різниці між нормальною рухливістю та дефектом сперми у контрольних птахів, які отримували енрофлоксачин, не було виявлено. На вагу яєчок, сережок і гребінців препарат не впливав. Вміст аскорбінової кислоти, загальний вміст білка, тестостерону та холестерину були подібними у контрольних групах та групах, що отримували енрофлоксаиин. Встановлено, ичо енрофлоксацин у застосованих дозах був безпечним для птиці. Задавання препарату “Енцин 10\%” півникам не впливало на концентрацію аскорбінової кислоти в яєчках, загальної кількості білка і холестерину. Ці показники активно беруть участь у сперматогенезі. Застосування препарату “Енцин 10\%” у терапевтичних дозах протягом 10 днів не мало негативного впливу на сперматогенез у півників.

Ключові слова: енрофлоксацин, стійкість до антибіотиків, півники, закони про добробут тварин.

\section{Вступ}

Сьогодні є тенденція до зростання рівня хронічних захворювань птиці бактеріального походження (Lashev et al., 2015). Застосування антибіотиків в птахівництві викликає все більше занепокоєння, адже це несе певні небезпеки (Mekala et al., 2014). Проблема антибіотикорезистентності мікроорганізмів визнана глобальною і в даний час $є$ одним 3 стратегічних завдань у всьому світі - стримування розвитку і розповсюдження антибіотикорезистентних мікроорганізмів. Але швидкість, з якою формується і розповсюджується стійкість мікроорганізмів до антибактеріальних препаратів, вражає. Препарати, які були ефективними до сьогодні втрачають свої властивості й використання їх вимушено обмежується (Ackermann et al., 2003). Фторхінолони - високоефективні синтетичні антибіотики широкого спектру антимікробної дії, які застосовуються для лікування бактеріальних інфекцій уже 40 років (Papich \& Riviere, 2001; Mekala et al., 2014). Це препарати із специфічним механізмом дії на бактеріальні клітини. Вони блокують фермент ДНКгіразу бактеріальної клітини, внаслідок чого знижується активність ферменту та унеможливується суперспіралізаціця хромосом.

Це призводить до порушення поділу бактеріальної клітини (Stojkovski, 2001; Yolande, 2005). Термін фторхінолони відображає дві основні особливості їх хімічної будови і належність до класу хінолінів та наявність у структурі молекули фтору в шостому положенні гетерациклічної системи. Значення атому фтору, обов'язково у шостому положенні хінолінового циклу, є вирішальним для проявлення антимікробної активності та широти спектру дії. Заміна фтору на інший галоїд, призводить до зниження антимікробної активності (Ackermann et al., 2003). Фторхінолони четвертого покоління отримані шляхом введення до їх складу атому фтору, що кардинально змінило антибактеріальну активність і фармакокінетику препаратів (Posyniak et al., 2002; Haritova et al., 2011). В клінічну практику успішно впроваджено моксифлоксацин, гатифлоксацин, енрофлоксацин, енрофлокс з високою ефективністю щодо анаеробів. Фторхінолони швидко створюють бактерицидну концентрацію в організмі моногастричних тварин і дещо повільніше у тварин 3 багатокамерним шлунком (Bachoual et al., 2001). Вони добре надходять в органи і тканини і створюють в них концентрацію, як у крові, а в деяких випадках і вищу (Bachoual et al., 2001).

Важливою фармакологічною властивістю антибіотиків групи фторхінолонів $є$ широка дистрибуція їх у тканини, легке проникнення через біологічні бар'єри, створення високої концентрації у позаклітинній рідині та цитоплазмі клітин фторхінолонів - єдиної думки у дослідників немає. За 20 років застосування офлоксацину в клінічній практиці, вказують одні автори (Haritova et al., 2011), чутливість ентеробактерій практично не змінилася. Мало резистентних штамів виділено поміж шігел, коринебактерій, колі бактерій, гемофільної палички. Інші автори (Ackermann et al., 2003) зазначають, що проблема резистентності бактерій до фторхінолонів має практичне значення в птахівництві, якщо антибіотики застосовують для профілактики бактеріальних захворювань протягом тривалого часу (Souza et al., 2002; NOAH, 2010).

Описують фторхінолони як надзвичайно безпечні засоби для використання. Нічого не повідомляється про їхній несприятливий вплив на розмноження. Але використання цих препаратів у високих дозах, як повідомляється, викликає токсичні ефекти, включаючи інгібування нейромедіатор гамма-аміномасляної кислоти, розлади центральної нервової системи (ЦНС), судоми, проблеми 3 очима та антропатію (Yolande, 2005; Haritova et al., 2011), але бракує інформації про їхній вплив на репродуктивні функції.

Метою нашого дослідження було дослідити сперму півників після застосування енрофлоксацину і визначити метаболіти.

\section{Матеріал і методи досліджень}

Дослідження проводили в умовах віварію клініки ветеринарного факультету та лабораторії кафедри епізоотології та паразитології Сумського національного аграрного університету.

В дослід були взяті півні у віці 20-23 тижні, які утримувались в металевих клітках по 5-6 особин згідно 3 вимогами комітету біоетики. В приміщеннях було 15 годинне штучне освітлення і вільний доступ до їжі та води. Птицю поділили на 4 групи по 20 голів у кожній. Птиці групам 1, 2 та 3 задавали препарат 
“Енцин 10\%” (НВФ “Бровафарма”, Україна) у кількості 10, 20 та 40 мг/кг ваги тіла відповідно. Препарат розводили у воді і задавали щодня протягом 10 діб.

Контрольною була група № 4, яка отримували лише воду без препарату.

В кінці досліду від півнів була відібрана сперма методом механічної стимуляції.

Зразки сперми розводили в 10 раз у 2,9\% розчині дегідрату цитрату натрію і ретельно змішували для оцінки прогресивної моторики та концентрації сперми.

Були зроблені мазки, які були забарвленні еозиннігросином. Після забою півників швидко відбирали сіменники, зважували та заморожували у рідкому азоті та зберігали при $-21^{\circ} \mathrm{C}$ до проведення аналізу. Також відбирали і зважували гребінці та сережки.

При проведенні біохімічного аналізу визначали концентрацію тестостерону в яєчках методом радіоімунологічного аналізу (RIA) 3 використанням комплекту RIA Amersham (код TRK 600).

Відновлення становило 70\%, результати були 3 урахуванням втрат, варіація аналізу становила $45 \%$. Загальний холестерин i аскорбінову кислоту оцінювали спектрофотометрично (спектрофотометр Cecil CE373) методами Knobil et al. та Майкель відповідно.
Загальний білок оцінювали методом Біурета (Sigma Kit No. 540). При проведенні статистичного аналізу використовували тест Стьюдента для оцінки статистичного показника різниці між засобами та ймовірністю (Р).

Значення $(\mathrm{P}<0,05)$ має статистичне значення.

\section{Результати та їх обговорення}

Препарат “Енцин 10\%” належить до групи фторхінолонів і має широкий спектр антибактеріальної дії. Пригнічує ріст і розвиток грампозитивних і грамнегативних бактерій - Staphylococcus aureus, Streptococcus spp., Clostridium perfringens, Corynebacterium spp., Escherichia coli, Haemophilus spp., Salmonella spp., Pastrurella spp., Pseudomonas aeruginosa, Bordetella spp., Campylobacter spp., Proteus spp., а також Mollicutes spp. Механізм дії полягає в інгібуванні активності ферменту гірази, що впливає на реплікацію спіралі ДНК в ядрі бактеріальної клітини.

Дію препарату “Енцин 10\%” (д. р. енрофлоксацин) на вторинні статеві ознаки показано в таблицях 1 і 2. Встановлено, що вага сім'яників, гребінця та сережок не змінилась під впливом енрофлоксацину, це дає можливість припустити, що кількість андрогену не було змінено.

\section{Таблиця 1}

Середня маса сім’яників, гребінців та сережок півників при різних дозах енрофлоксацину $(\mathrm{n}=20)$

\begin{tabular}{lcccc}
\hline \multirow{2}{*}{ Органи } & \multirow{2}{*}{ контроль } & \multicolumn{3}{c}{ енрофлоксацин (мг/кг) } \\
\cline { 3 - 5 } Сім'яники & $1.41 \pm 0,09$ & 10 & 20 & 40 \\
Сережки & $0.25 \pm 0,07$ & $0.26 \pm 0,02$ & $1.38 \pm 0,06$ & $1.38 \pm 0,04$ \\
Гребінець & $0.51 \pm 0,08$ & $0.52 \pm 0,03$ & $0.24 \pm 0,05$ & $0.25 \pm 0,05$ \\
\cline { 3 - 5 } & & $0.53 \pm 0,06$ & $0.51 \pm 0,03$
\end{tabular}

Доведено, що немає значної різниці між контрольною та дослідної групами $(\mathrm{P}<0,05)$

\section{Таблиця 2}

Середній відсоток прогресивно рухомих сперматозоїдів, дефектів сперми та нормальної сперми в контролі та досліді $(\mathrm{n}=20)$

\begin{tabular}{lccrr}
\hline & \multirow{2}{*}{ Сперма } & \multirow{2}{*}{ контроль } & \multicolumn{3}{c}{ енрофлоксацин (мг/кг) } \\
\cline { 3 - 5 } & & 10 & 20 & 40 \\
\hline Нормальна & $85.2 \pm 0,08$ & $83.3 \pm 0,06$ & $82.1 \pm 0,08$ & $81 \pm 0,07$ \\
Рухливість & $84.8 \pm 0,04$ & $82.1 \pm 0,05$ & $80.2 \pm 0,06$ & $83.2 \pm 0,05$ \\
Дефекти & $14,8 \pm 0,03$ & $16,7 \pm 0,04$ & $17,9 \pm 0,05$ & $19.1 \pm 0,04$ \\
\hline
\end{tabular}

Встановлено, що немає значної різниці між контрольною та обробленою групами $(\mathrm{P}<0,05)$

Але при підвищенні дози енрофлоксацину рухливість сперміїв знижувалась Енрофлоксацин не мав негативного впливу на тестостерон яєчок, не було впливу і на інші показники сперми (табл. 3).

\section{Таблиця 3}

Вплив енрофлоксацину на концентрації тестостерону, аскорбінової кислоти, загального білка і холестерину в сіменниках $(\mathrm{n}=20)$

\begin{tabular}{lrrrr}
\hline \multicolumn{1}{c}{ Параметри сперми } & \multirow{2}{*}{ контроль } & \multicolumn{3}{c}{ енрофлоксацин (мг/кг) } \\
\cline { 3 - 5 } & & \multicolumn{1}{c}{20} & \multicolumn{1}{c}{40} \\
\hline Тестостерон (мкг/г) & $13,3 \pm 0,07$ & $14,1 \pm 0,05$ & $13,2 \pm 0,04$ & $14,2 \pm 0,08$ \\
Аскорбінова кислота (мкмоль/г тканини) & $22,3 \pm 0,06$ & $23,1 \pm 0,04$ & $21,4 \pm 0,05$ & $22,1 \pm 0,07$ \\
Загальний білок (мг/г тканини) & $187,1 \pm 0,08$ & $182,2 \pm 0,06$ & $186,4 \pm 0,05$ & $190,2 \pm 0,06$ \\
Холестерин (мкмоль/г тканини) & $12,6 \pm 0,03$ & $12,5 \pm 0,04$ & $12,4 \pm 0,05$ & $12,7 \pm 0,05$ \\
\hline
\end{tabular}

Доведено вірогідність отриманих результатів $(\mathrm{P}<0,05)$ 
Тривалість задавання препарату “Енцин 10\%” була такою ж, як зазвичай використовують цей препарат для лікування бактеріальних хвороб птиці. Дози були дещо завищені - 3 метою точного визначення негативних наслідків на сперматогенез.

\section{Висновки}

Задавання препарату "Енцин 10\%" півникам не впливало на концентрацію аскорбінової кислоти в яєчках, загальної кількості білка і холестерину. Ці показники активно беруть участь у сперматогенезі. Таким чином, можна зробити висновок, що застосування препарату “Енцин 10\%” у терапевтичних дозах протягом 10 днів не мало негативного впливу на сперматогенез у півників.

\section{References}

Ackermann, G., Tang-Feldman, Y.J., Schaumann, R., Henderson, J.P., Rodloff, A.C., Silva, J., \& Cohen, S.H. (2003). Antecedant use of fluoroquinolones is associated with resistance to moxiflocacin in Clostridium difficile. Clin Microbiol. Infect., 9(6), 526-530. doi: 10.1046/j.1469-0691.2003.00559.x.

Bachoual, R., Ouabdesselam, S., Mory, F., Lascols, C., Soussy, C.J., \& Tankovic, J. (2001). Single or double mutational alterations of gyrA associated with fluoroquinolone resistance in Campylobacter jejuni and Campylobacter coli. Microbiol. Drug Resist., 7(3), 257-261. doi: 10.1089/10766290152652800.

Haritova, A., Urumova, V., Lutckanov, M., Petrov, V., \& Lashev, L. (2011). Pharmacokinetic-pharmacodynamic indices of enrofloxacin in Escherichia coli O78/H12 infected chickens. Food Chem. Toxicol., 49(7), 1530 1536. doi: 10.1016/j.fct.2011.03.044.

Knoll, U., Glünder, G., \& Kietzmann, M. (1999). Comparative study of the plasma pharmacokinetics and tissue concentrations of danofloxacin and enrofloxacin in broiler chickens. J. Vet. Pharmacol. Therap., 22(4), 239-246. doi: 10.1046/j.1365-2885.1999.00217.x.

Lashev, L.D., Dimitrova D.J., Milanova, A., \& Moutafchieva, R.G. (2015). Pharmacokinetics of enrofloxacin and marbofloxacin in Japanese quails and common pheasants. Br. Poult. Sci., 56(2), 255-261. doi: 10.1080/00071668.2014.998989.

Mekala, P., Jagadeeswaran, A., Arivuchelvan, A., Senthilkumar, P., Nanjappan, K., \& Gopala Krishnamurthy, T.R. (2014). Pharmacokinetics of enrofloxacin after single intravenous and oral bolus administration in broiler chicken. Intern. J. Advanced Vet. Sci. Technol., 3, 99-105. http://scientific.cloudjournals.com/index.php/IJAVST/article/view/Sci-190.

National Office of Animal Health, NOAH (2010). The Use of Fluoroquinolones in Animal Health, Briefing Document No.18. www.noahcompendium.co.uk.

Papich, M.G., \& Riviere, J.E. (2001). Fluoroquinolones antimicrobial drugs. In: Veterinary Pharmacology and Therapeutics, H.R. Adams (ed.), 5th edition, Iowa State University Press, Iowa, 898-917.

Posyniak, A., Zmudzki, J., \& Niedzielska, J. (2002) Liquid chromatography analysis of enrofloxacin and ciprofloxacin in chicken blood spotted on filter-paper disks. J Chromatogr B Analyt Technol Biomed Life Sci, 780(2), 309-314. doi: 10.1016/s15700232(02)00540-8.

Souza, M.J., Bittencourt, C., \& Morsch, L. (2002). LC determination of enrofloxacin. J Pharm Biomed Anal, 28(6), 1195-1199. doi: 10.1016/s0731-7085(01)006732.

Stojkovski, V. (2001). Veterinary Clinical Biochemistry. 1st ed., Kiro Dandaro, Bitolya.

Toutain, P.L., Bousquet-Melou, A. (2004). Plasma terminal half-life. J. Vet. Pharmacol. Therap., 27(6), 427 439. doi: 10.1111/j.1365-2885.2004.00600.x.

Yolande, B. (2005). The Veterinary Formulary, 5th edition, Pharmaceutical Press, London, 163-219. 